\title{
Treatment of Wastewater Disposal from the General Hospital in Tuz Region Using Alum and Bentonite
}

\author{
Shno Mustafa Ali* \\ Department Civil Engineering, College of Engineering, Kirkuk University, Kirkuk, Iraq
}

\section{${ }^{*}$ Corresponding author: \\ Shno Mustafa Ali, \\ Department Civil \\ Engineering, College \\ of Engineering, Kirkuk \\ University, Kirkuk, Iraq. \\ E-mail: shnoma@yahoo. \\ com}

Received: 01 August 2019

Accepted: 03 September 2019

Published: 01 December 2019

DOI

10.25156/pti.v9n2y2019.pp144-148

\section{A B S T R A C T}

The general hospital in Tuz town in Iraq suffers from the absence of a wastewater treatment plant, in which the disposals of the hospital are discharged directly into the sewerage system. The aim of this study is to use simple and basic methods for treating wastewater from the general hospital in Tuz Town using bentonite clay and alum with different dosages by methods of coagulation, flocculation, and sedimentation using Jar test, to measure the general characteristics of wastewater such as chemical oxygen demand (COD), biochemical oxygen demand $\left(\mathrm{BOD}_{5}\right)$, potential of hydrogen (PH), electrical conductivity $(\mathrm{EC})$, nitrates $\left(\mathrm{NO}_{3}\right)$, phosphates $\left(\mathrm{PO}_{4}\right)$, hardness, calcium $(\mathrm{Ca})$, magnesium $(\mathrm{Mg})$, turbidity, chlorides $(\mathrm{Cl})$, and sulfates $\left(\mathrm{SO}_{4}\right)$. The results showed that bentonite clay was more effective than alum in removing pollutants from wastewater. The removal efficient of $C O D$ and $B^{\circ O D_{5}}$ was $65 \%$ and $57 \%$, respectively, at the optimum dosage of bentonite clay, whereas the efficient removal of COD and $\mathrm{BOD}_{5}$ using alum was $60 \%$ and $48 \%$, respectively. Higher efficiency removal of turbidity was $75 \%$ for bentonite and $65 \%$ for alum; the higher value of efficiency removal was $68 \%$ for $\mathrm{NO}_{3}$ and $60 \%$ for $\mathrm{PO}_{4}$ while the higher efficiency using the treatment with alum was $58 \%$ for $\mathrm{NO}_{3}$ and $49 \%$ for $\mathrm{PO}_{4}$. The changing in the value of $\mathrm{pH}$ was decreased with increasing the dosages of alum, for the first dosage $20 \mathrm{mg} / \mathrm{l}$, the value of $\mathrm{PH}$ was 7.1 then it was decreased to reach 6.2 at $120 \mathrm{mg} / \mathrm{l}$, whereas bentonite shows increasing in value of $\mathrm{PH}$ to reach 7.6 at dosage of $120 \mathrm{mg} / \mathrm{l}$.

Keywords: Alum and bentonite; Coagulation; Flocculation; Hospital; Jar test; Wastewater

\section{INTRODUCTION}

Wastewater from hospitals causes many environmental hazards. These problems are different in terms of the nature and activity of the hospital (Jolibios and Gurbet, 2006). Wastewater effluent from hospitals has been increasing during recent decades due to developments in medical services and products (Amouei et al., 2015). Hospital wastewater contains infections, pathogens, toxoid, biodegradable, and radioactive contamination that can cause pollution and health problems (Prayitno et al., 2013). Wastewater that is generated in different sectors of the hospital including patient wards, clinical wards, laboratories, surgery units, laundries, and poses a quite variable composition depending on the activities involved (Kumarathilaka et al., 2015). One of the major environmental concerns due to hospital effluents is their discharge into urban sewerage systems without adequate treatment and this could be a negative impact on the public health and ecological balance (Gautam et al., 2007). Gersberg et al. (1988) treated municipal wastewater using bentonite clay, where the value of chemical oxygen demand (COD) in effluent wastewater was $<20 \mathrm{mg} / \mathrm{l}$. Hobson and Pohl, 1973, mentioned that the organic particles in wastewater may be adsorbed by clay mineral; therefore, using this method the clay can be acted as treatment materials for wastewater disposals. Ghawi and Kris (2010) studied the treatment of wastewater in Dewanyia city in Iraq using alum and ferric chloride as a coagulant. In their study, the removal of all colloidal suspended solids was at dose $200 \mathrm{ppm}$ which was a mixer of alum and ferric chloride, which improved the COD removal about 40\%. Abawee and Elea in 2009 treated wastewater from Khansa hospital of Mosul city in Iraq using some types of muds (bentonite, kaoline, and ninavite). They claimed that the bentonite had the best removal of $\mathrm{COD}$, biochemical oxygen demand $\left(\mathrm{BOD}_{5}\right)$, oil, and phosphate. Mustafa (2002) used a mixture of kaoline and ninavite with equal ratios for removing some heavy metals $\mathrm{Cd}, \mathrm{Hg}$, and $\mathrm{Pb}$ from wastewater; the efficiency of removal Cd was $80 \%$, while the removal of $\mathrm{Hg}$ and $\mathrm{Pb}$ was 95\%. Hamidawi and Ali (2014) used leaf extract concarpus as a coagulant or as coagulant aid with alum and ferric chloride to remove water turbidity. They concluded that reduction ratios of turbidity were higher in using leaf extract with alum or ferric chloride compared with alum or ferric chloride individually. The purpose of the current study is to examine the efficiency 
of bentonite and alum for the treatment of wastewater produced from Tuz hospital.

\section{MATERIALS AND METHODS}

Jar test is used for representing the treatment process by coagulation, flocculation, and sedimentation using alum and bentonite clay as a coagulant, the wastewater poured in the beakers of Jar test with adding each coagulant by different doses to obtain the optimal dose. The rapid mix was $150 \mathrm{rpm}$ for 1 minute, and then slow mix was $50 \mathrm{rpm}$ for $30 \mathrm{~min}$ after that the mixers were stopped. Then following Metcalf and Eddy (1979), the solutions were settled for $30 \mathrm{~min}$. Tests were conducted for the settled water as: $\mathrm{COD}, \mathrm{BOD}_{5}$, potential of hydrogen $(\mathrm{PH})$, electrical conductivity $(\mathrm{EC})$, nitrates $\left(\mathrm{NO}_{3}\right)$, phosphates $\left(\mathrm{PO}_{4}\right)$, hardness, calcium (Ca), magnesium $(\mathrm{Mg})$, turbidity, chlorides $(\mathrm{Cl})$, and sulfates $\left(\mathrm{SO}_{4}\right)$ to get the best removal efficiency of the pollutants from the wastewater. All these tests were conducted according to standard methods of examinations water and wastewater (APHA, AWWA, and WEF, 1998) at the sanitary laboratory of Kirkuk University/College of Engineering. The samples were taken weekly from April 2018 to July 2018 after pumping it directly to the aeration tank. The most characteristics of wastewater before treatment in Tuz general hospital are presented in Table 1.

\section{RESULTS AND DISCUSSION}

Figure 1 shows the efficiency removal of COD, where the optimum dose of bentonite was $40 \mathrm{mg} / 1$ with efficiency $65 \%$. It is observed that the bentonite was more efficient than alum in removing COD from wastewater of Tuz

$\begin{aligned} & \text { Table 1: Most important characteristics of wastewater in Tuz } \\
& \text { general hospital }\end{aligned}$
\begin{tabular}{|llc|}
\hline No. & Parameter & The range \\
\hline 1. & $\mathrm{COD}$ & $110-485 \mathrm{mg} / \mathrm{l}$ \\
2. & $\mathrm{BOD}_{5}$ & $120-340 \mathrm{mg} / \mathrm{l}$ \\
3. & $\mathrm{PH}$ & $6.2-7.8$ \\
4. & $\mathrm{EC}$ & $420-675 \mu \mathrm{s} / \mathrm{cm}$ \\
5. & $\mathrm{Total}$ hardness & $240-290 \mathrm{mg} / \mathrm{l}$ \\
6. & $\mathrm{Ca}$ & $45-150 \mathrm{mg} / \mathrm{l}$ \\
7. & $\mathrm{Mg}$ & $10.3-22.6 \mathrm{mg} / \mathrm{l}$ \\
8. & $\mathrm{NO}_{3}$ & $0.8-1.62 \mathrm{mg} / \mathrm{l}$ \\
9. & $\mathrm{PO}_{4}$ & $1.2-6.8 \mathrm{mg} / \mathrm{l}$ \\
10. & $\mathrm{SO}_{4}$ & $110-220 \mathrm{mg} / \mathrm{l}$ \\
11. & $\mathrm{Cl}_{1}$ & $21-45 \mathrm{mg} / \mathrm{l}$ \\
12. & $\mathrm{Turbidity}^{2}$ & $50-82 \mathrm{NTU}$ \\
\hline
\end{tabular}

COD: Chemical oxygen demand, $\mathrm{BOD}_{5}$ : Biochemical oxygen demand, $\mathrm{PH}$ : Potential of hydrogen, EC: Electrical conductivity, Ca: Calcium,

Mg: Magnesium, $\mathrm{NO}_{3}$ : Nitrates, $\mathrm{PO}_{4}$ : Phosphates, $\mathrm{SO}_{4}$ : Sulfates, $\mathrm{Cl}$ : Chlorides hospital. Figure 2 shows the performance of coagulants in removing $\mathrm{BOD}_{5}$ from the wastewater of Tuz general hospital. As it can be seen, the highest efficiency removal was $57 \%$ at bentonite dosage $60 \mathrm{mg} / \mathrm{l}$, also shown in Figures 3 and 4, it is clear that the bentonite was more efficient than alum in removing $\mathrm{NO}_{3}$ and $\mathrm{PO}_{4}$. The higher value of efficiency removal was $68 \%$ for $\mathrm{NO}$ and $60 \%$ for $\mathrm{PO}_{4}$. From Figures 5-10, it is observed that the optimum dosage of removal of the hardness, $\mathrm{Ca}, \mathrm{Mg}, \mathrm{SO}_{4}, \mathrm{Cl}$, and $\mathrm{EC}$ was for the treatment using

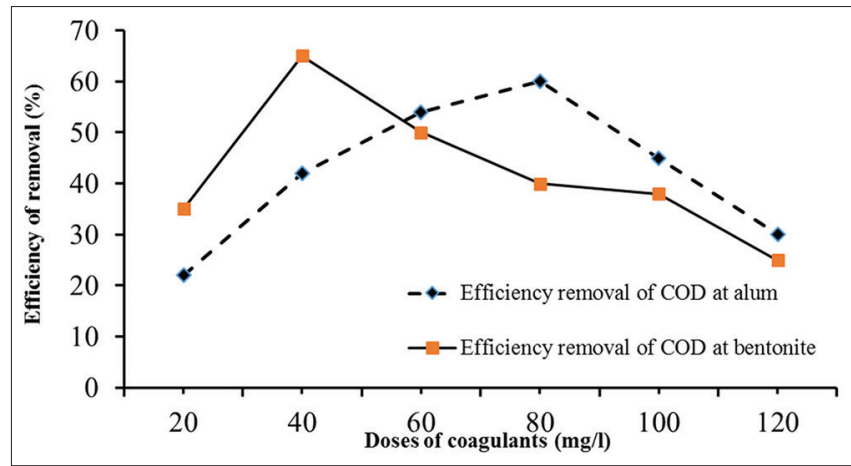

Figure 1: Efficiency removal of chemical oxygen demand using alum and bentonite

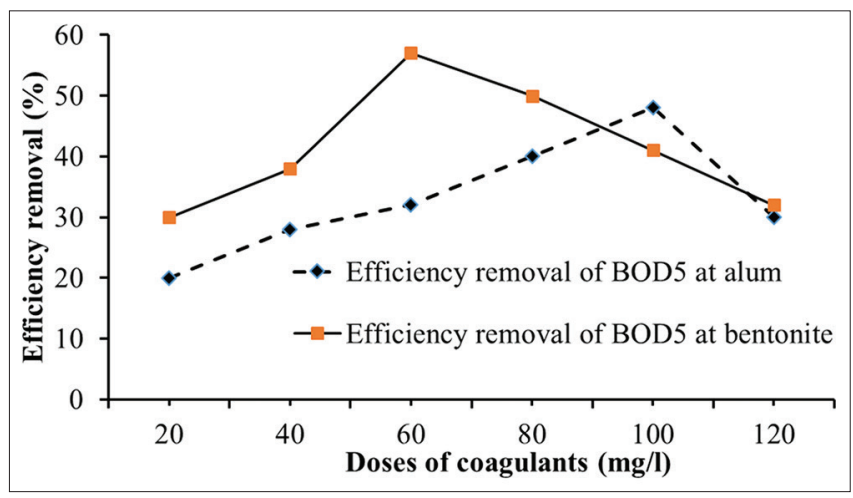

Figure 2: Efficiency removal of biochemical oxygen demand using alum and bentonite

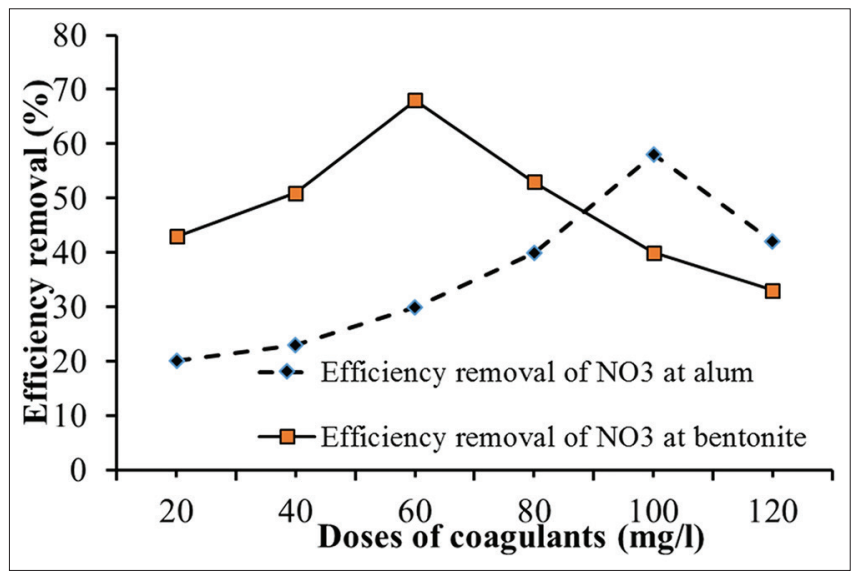

Figure 3: Efficiency removal of nitrates using alum and bentonite 


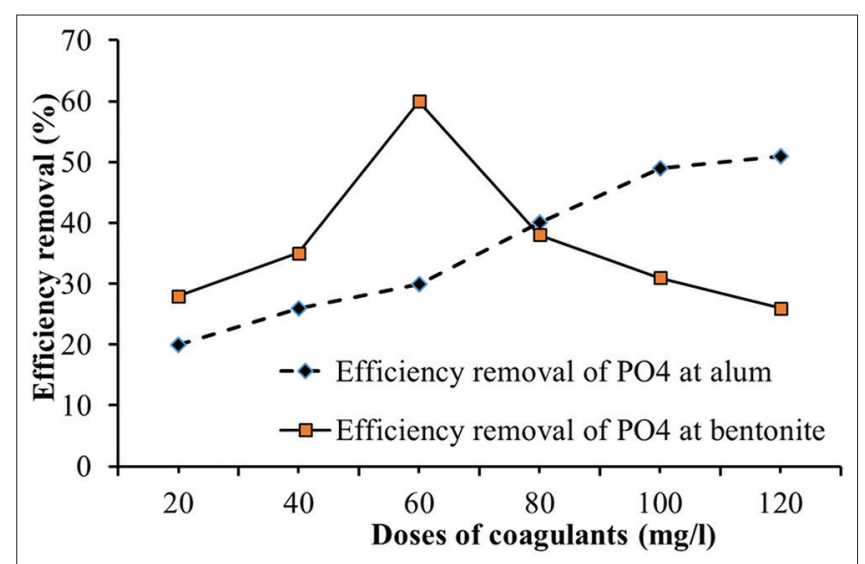

Figure 4: Efficiency removal of phosphates using alum and bentonite

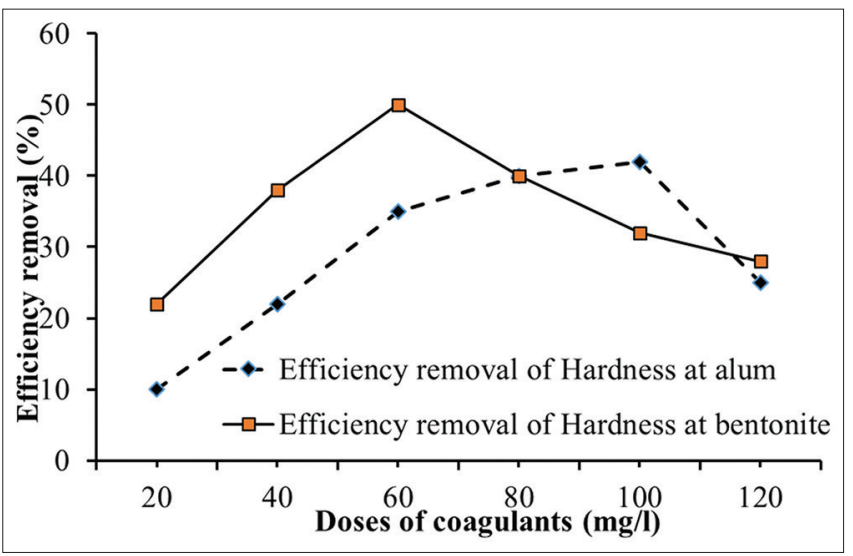

Figure 5: Efficiency removal of hardness using alum and bentonite

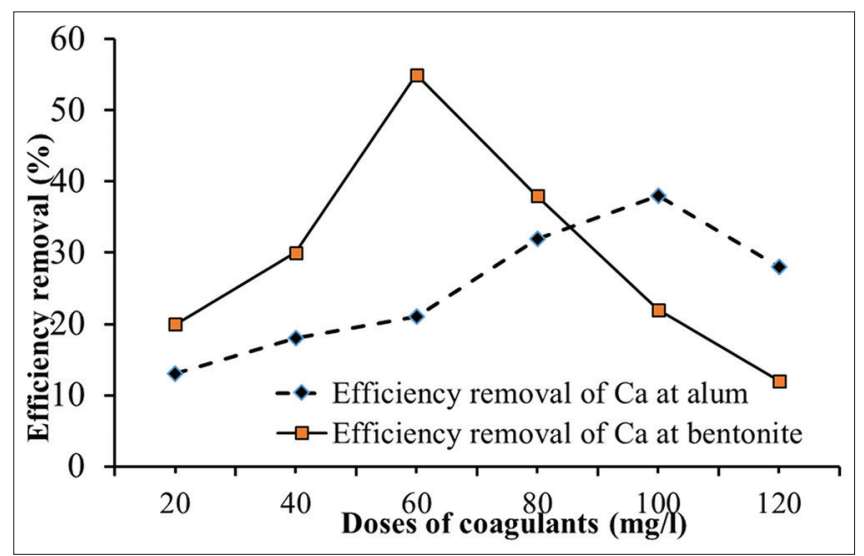

Figure 6: Efficiency removal of calcium using alum and bentonite

bentonite clay. In Figure 11, the changing in the value of $\mathrm{PH}$ was decreased with increasing the doses of alum; for the first dosage $20 \mathrm{mg} / \mathrm{l}$, the value of $\mathrm{PH}$ was 7.1, then it is decreased to reach 6.2 at $120 \mathrm{mg} / \mathrm{l}$. Whereas bentonite shows increasing in the value of $\mathrm{pH}$ to reach 7.6 at dosage $120 \mathrm{mg} / \mathrm{l}$. Figure 12 shows the efficiency removal of turbidity from wastewater in Tuz general

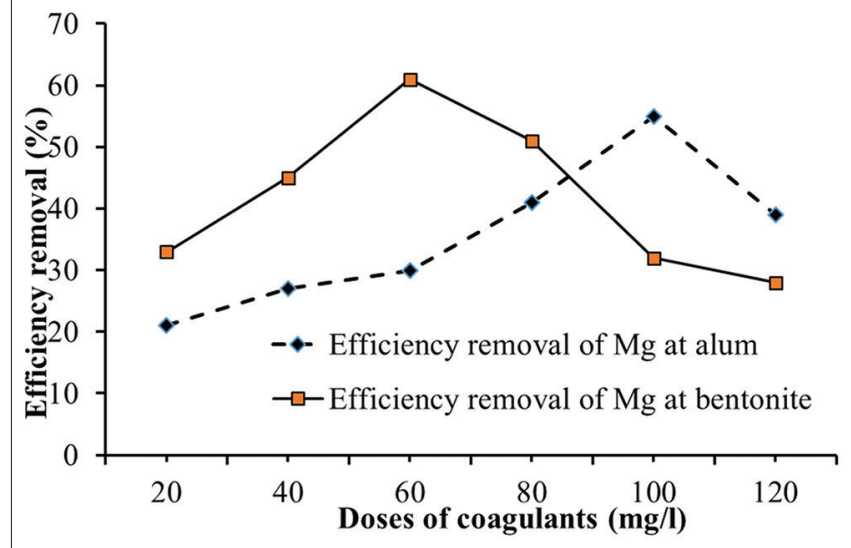

Figure 7: Efficiency removal of magnesium using alum and bentonite

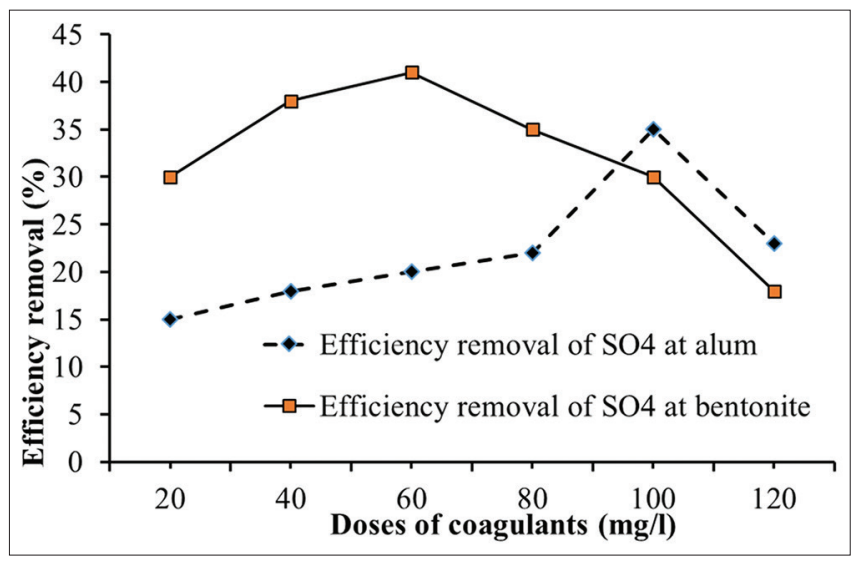

Figure 8: Efficiency removal of sulfates using alum and bentonite

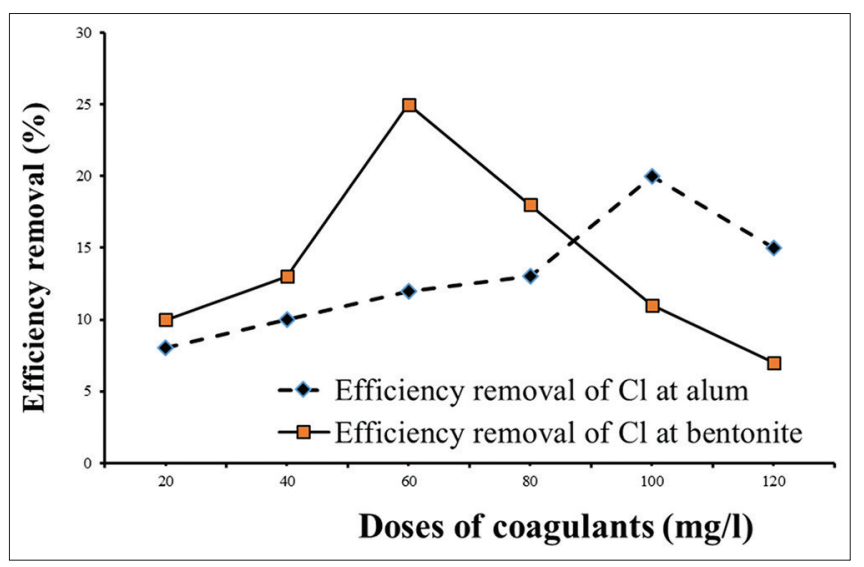

Figure 9: Efficiency removal of chlorides using alum and bentonite

hospital, each coagulants alum and bentonite were effective in the removal of turbidity, the higher efficiency removal of turbidity was $75 \%$ at bentonite and $65 \%$ for alum. In general, all the results showed that bentonite performs better than the alum in removing the pollutants especially at dosage $60 \mathrm{mg} / \mathrm{l}$, except in removing COD was at dosage $40 \mathrm{mg} / \mathrm{l}$. However, alum shows efficiency 


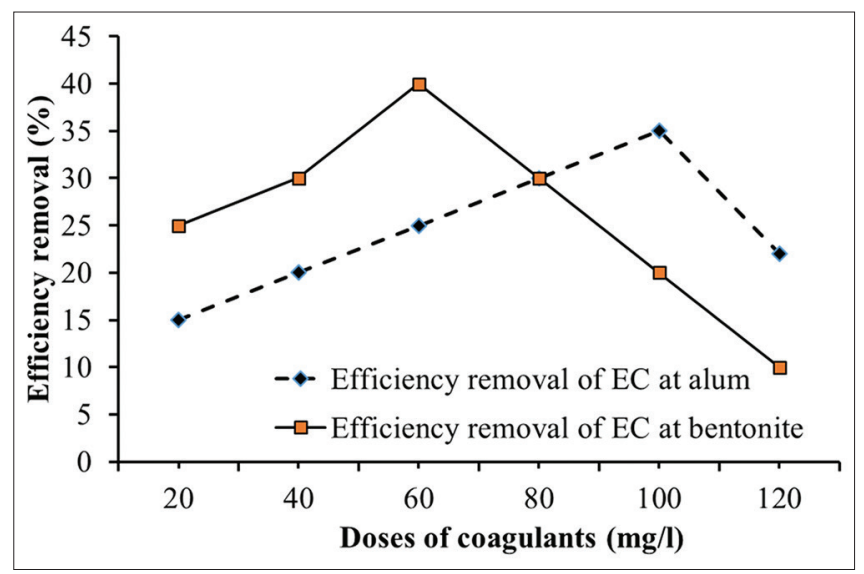

Figure 10: Efficiency removal of electrical conductivity using alum and bentonite

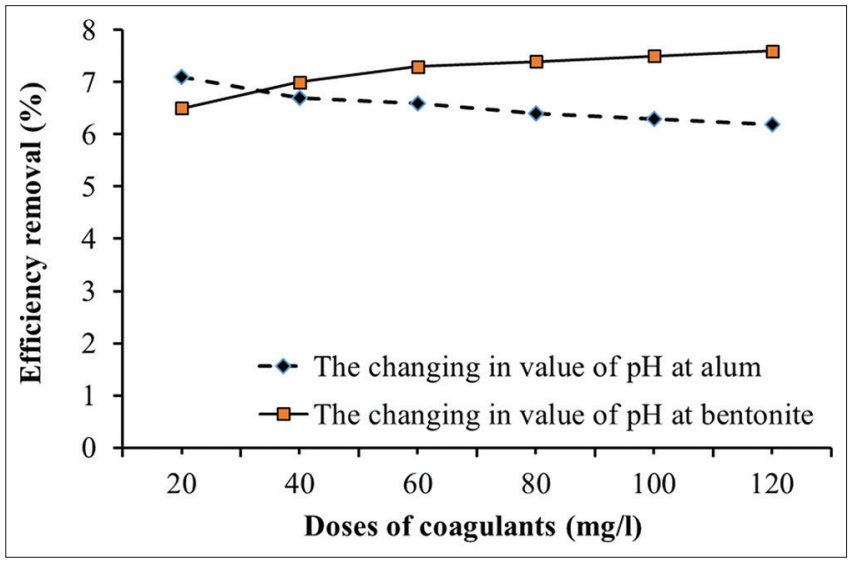

Figure 11: The changing in the value of the potential of hydrogen using alum and bentonite

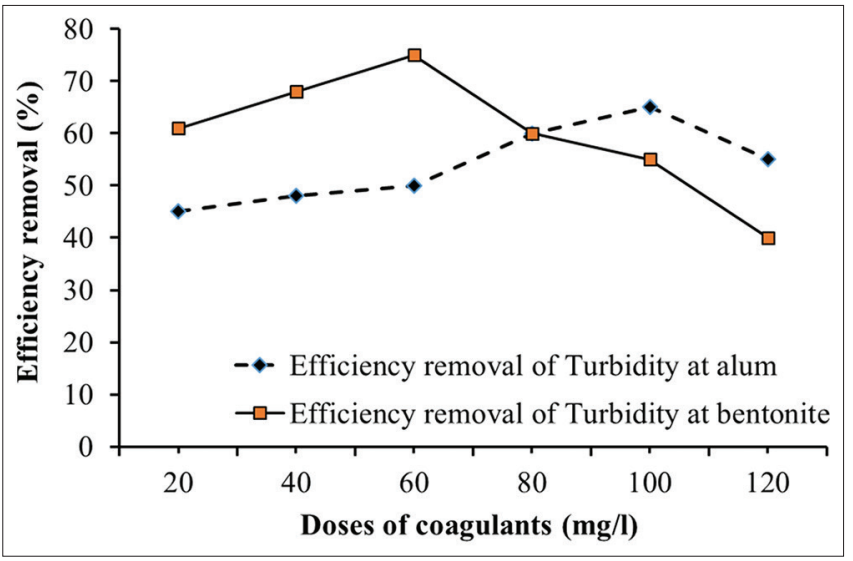

Figure 12: Efficiency removal of turbidity using alum and bentonite

removal for all the pollutants at a dosage $100 \mathrm{mg} / \mathrm{l}$. This high performance of bentonite clay for removing the pollutants from wastewater is due to its ability in adsorption on particle surfaces because it contains silicon ion which is a cation that attracted to the anion particles and flocculate gradually (Kawamura, 1991).

\section{CONCLUSIONS}

In this study, the treatment of wastewater disposal from the general hospital in Tuz region in Iraq was performed using the alum and bentonite. Based on the results, the following conclusions are drawn:

- The results showed that bentonite clay was more effective in the removal of pollutants from wastewater that discharged by the general hospital in Tuz especially at dose $60 \mathrm{mg} / \mathrm{l}$

- Efficiency removal of alum was less than bentonite clay, where the optimum dosage was $100 \mathrm{mg} / \mathrm{l}$

- Efficiency removal of COD using bentonite was $65 \%$, whereas for $\mathrm{BOD}_{5}$ was $57 \%$

- Efficiency removal of $\mathrm{NO}_{3}$ and $\mathrm{PO}_{4}$ using bentonite was $68 \%$ and $60 \%$, respectively

- The changing in value of PH was increased using bentonite clay, whereas treatment using alum showed decreasing of $\mathrm{PH}$ value

- Each coagulant alum and bentonite were effective in the removal of turbidity; the higher efficiency removal of turbidity was $75 \%$ for bentonite and $65 \%$ for alum.

\section{REFERENCES}

Abawee, S. A. and Elea, H. N. 2009. Wastewater treatment of Khanssa hospital by using some types of muds. Al-Rafidain Eng. J. 17(5): 49-55.

Amouei, A., H. Asgharina, H. Fallah, H. Faraji, R. Barari and D. Naghipour. 2015. Characteristics of effluent wastewater in hospital of Bobal university of medical science, Babol, Iran. Health Scope. 4(2): e23222.

APHA, AWWA and WEF. 1998. Standard Methods for the Examination of Water and Wastewater. $19^{\text {th }}$ ed. APHA-AWWAWEF, Washington, DC.

Gautam, A. K., S. Kumar and P. C. Sabumon. 2007. Preliminary study of physic-chemical treatment options for hospital wastewater. J. Environ. Manage. 83(3): 298-306.

Gersberg, R. M., S. R. Lyon, R. Brenner and B. V. Elkin. 1988. Performance of clay alum flocculation (CCBA) process for virus removal from municipal wastewater. Water Res. 22(11): 1449.

Ghawi, A. H. and J. Kris. 2010. Study for Wastewater Treatment in Iraq Using Coagulants, January, Conference Paper from Research Gate.

Hamidawi, A. K. and N. M. Ali. 2014. The use of leaf extract concarpus as coagulant or as coagulant aid with alum and ferric chloride to remove water turbidity. J. Basra Res. Sci. 40: 28-41.

Hobson, G. D. and W. Pohl. 1973. Modern Petroleum Technology. Applied Science Publishers, England. p310.

Jolibios, B. and M. Gurbet. 2006. Hospital wastewater genotoxicity. Ann. Occup. Hyg. 50(2): 189-196.

Kawamura, S. 1991. Effectiveness of natural polyelectrolytes in water treatment. J. AWWA. 83(10): 88.

Kumarathilaka, P., Y. Jayawardhana, W. Dissanayaka, I. Herath, L. Weerasundara and M. Vithange. 2015. General Characteristics of Hospital Wastewater from Three Different Hospitals in 
Srilanka, $6^{\text {th }}$ International Conference on Structural Engineering and Construction Management, Kandy, Srilanka, $\left(11^{\text {th }}-13^{\text {th }}\right)$ December, p39-43.

Mustafa, M. H. 2002. The Used of Mixed Ninavite and Kaoline for the Removal of Some Heavy Metal $(\mathrm{Cd}, \mathrm{Hg}$ and $\mathrm{Pb}$ ) from their Effluent Ph.D Science Thesis, University of Mosul, College of
Science, Mosul.

Metcalf and Eddy, Inc. 1979. Wastewater Engineering Treatment, Disposal and Reuse. $2^{\text {nd }}$ ed. McGraw Hill, New York.

Prayitno, Z. Kusuma, B. Yanuwiadi and R. Laksmono. 2013. Study of hospital wastewater characteristics, Malang city. Int. J. Eng. Sci. 2(2): 13-16. 